\title{
COPULA FRANK UNTUK PERHITUNGAN VALUE AT RISK PORTOFOLIO BIVARIAT PADA MODEL EXPONENTIAL GENERALIZED AUTOREGRESSIVE CONDITIONAL HETEROSCEDASTICITY
}

\author{
Eka Anisha ${ }^{1}$, Di Asih I Maruddani ${ }^{2}$, Suparti $^{3}$ \\ 1,2,3 Departemen Statistika, Fakultas Sains dan Matematika, Universitas Diponegoro \\ e-mail: ekaanisha29@gmail.com
}

\begin{abstract}
Stocks are one type of investment that promises return for investors but often carries a high risk. Value at Risk $(\mathrm{VaR})$ is a measuring tool that can calculate the amount of the worst loss that occurs in a stock portfolio with a certain level of confidence and within a certain time period. In general, financial data have a high volatility value, which causes the residuals are not normally distributed. ARCH/GARCH modoel is used to solve the heteroscedasticity problem. If the data also have an asymmetric effect, it is modelled with Exponential GARCH model. Copula-Frank is part of the Archimedian copula which is used to solve empirical cases. The data on this study were BBCA and KLBF stock price return data in the observation period 30 December $2011-6$ December 2019. Furthermore, to test the validity of the VaR model, a backtesting test will be carried out using the Kupiec Test. The results showed that the best model used for BBCA stocks was ARIMA $(1,0,1)$ EGARCH $(1,1)$ and for KLBF stocks was ARIMA $(1,0,1)$ EGARCH $(1,2)$. The amount of risk with a 95\% confidence level used a combination of the EGARCH and Copula-Frank models was $2.233 \%$ of today's investment. Based on the backtesting test used the Kupiec Test, the VaR model of the portfolio obtained was declared valid.
\end{abstract}

Keywords: Value at Risk, EGARCH, Copula-Frank, Backtesting, Kupiec Test.

\section{PENDAhuluan}

Kehidupan masyarakat yang sudah sangat berkembang diikuti dengan kebutuhan yang sangat banyak membuat masyarakat harus cermat menyimpan uang atau modalnya untuk kebutuhan di masa mendatang yang tidak terduga. Salah satu caranya yaitu dengan berinvestasi. Ada dua pilihan aset yang dapat dipilih investor untuk berinvestasi, yaitu aset riil dan aset keuangan. Wujud dari aset keuangan dapat diwakili oleh sebentuk kertas sebagai bentuk bukti klaim pada pihak yang menerbitkan, contohnya adalah saham dan obligasi (Jones, 2007). Saham dapat didefinisikan sebagai tanda penyertaan atau pemilikan seseorang atau badan dalam suatu perusahaan atau perseroan terbatas (Darmadji, 2001). Pada umumnya tujuan investor melakukan investasi adalah untuk mendapatkan keuntungan maksimal dengan risiko yang minimal, sedangkan untuk memaksimalkan keuntungan (return) dan meminimalkan resiko (risk), maka seorang investor harus membentuk suatu portofolio saham.

Pembentukan portofolio ditujukan untuk memperoleh suatu investasi yang memberikan return yang sama namun memberikan risiko rendah, atau dengan risiko yang sama namun memberikan return yang lebih tinggi. Untuk mengetahui saham mana yang memiliki tingkat keuntungan yang tinggi dengan risiko tertentu serta meminimalkan risiko tersebut, salah satu metode analisis risiko yang dapat digunakan adalah Value at Risk (VaR). VaR merupakan alat ukur yang dapat menghitung besarnya kerugian terburuk yang terjadi pada portofolio saham dengan tingkat kepercayaan tertentu dan dalam periode waktu tertentu.

Pada umumnya data return finansial kebanyakan memiliki volatilitas yang tinggi dan biasanya memiliki kecenderungan berfluktuasi secara cepat dari waktu ke waktu sehingga varian dari residualnya akan selalu berubah setiap waktu atau tidak konstan. Hal ini disebut sebagai kasus heteroskedastisitas. Salah satu metode yang dapat digunakan untuk mengatasi masalah heteroskedastisitas, yaitu metode ARCH/GARCH. Model ARCH/GARCH mempunyai kelemahan dalam menangkap fenomena ketidaksimetrisan good news dan bad 
news pada volatilitas sektor keuangan, artinya antara gejolak positif ( good news) dan gejolak negatif (bad news) tidak seimbang. Menurut Tsay (2002), kelemahan model ARCH/GARCH tersebut bisa diperbaiki dengan menggunakan model GARCH asimetris yaitu Exponential Generalized Autoregressive Conditional Heteroscedasticity (EGARCH).

Pada kenyataanya dalam data keuangan banyak ditemukan data tidak berdistribusi normal dan terdapat ketergantungan di antara return saham. Sehingga diperkenalkan suatu alat yaitu copula untuk mengatasi masalah tersebut. Teori copula merupakan suatu alat yang sangat powerful untuk memodelkan distribusi gabungan karena tidak mensyaratkan asumsi normalitas dari data sehingga cukup fleksibel untuk berbagai bentuk data terutama untuk data return saham dan dapat menangkap tail dependence diantara masing-masing variabel. Copula Archimedian, memiliki beberapa anggota keluarga, yaitu copula Clayton, copula Gumbel dan copula Frank. Copula Frank cukup terkenal untuk beberapa alasan, yaitu copula Frank dapat menyatakan hubungan dependensi dalam positif maupun negatif, struktur dependensi copula Frank simetris, dan cakupan jarak dependensi yang diijinkan sangat luas (Arna et al, 2017). Selain itu, copula Frank adalah bagian dari copula Archimedian yang paling sering digunakan dan merupakan copula Archimedian yang paling dikenal dalam menyelesaikan kasus empiris (Cherubini et al, 2004).

$\mathrm{Xu}$ (2012) mengukur Value at Risk (VaR) portofolio dengan copula dan menunjukkan struktur dependensi. Dari berbagai metode pengukuran risiko yang dapat dilakukan, tentu akan timbul petanyaan bagaimana memilih metode terbaik dalam pengukuran risiko (perhitungan $\mathrm{VaR}$ ), hal tersebut dapat dilakukan dengan melakukan backtesting. Backtesting merupakan metode untuk mengevaluasi Value at Risk dengan memeriksa nilai-nilai yang dihasilkan pada periode yang lalu (Danielsson, 2011). Berdasarkan fenomena tersebut, penelitian ini bertujuan untuk menghitung nilai VaR dengan menggunakan kombinasi antara model asimetris Exponential Generalized Autoregressive Conditional Heteroscedasticity (EGARCH) dengan copula Frank, kemudian untuk menguji validitas model Value at Risk (VaR) maka akan dilakukan uji backtesting pada portofolio saham KLBF dan BBCA pada periode 30 Desember 2011 - 6 Desember 2019.

\section{TINJAUAN PUSTAKA}

\subsection{Stasioneritas}

a. Uji Stasioneritas dalam Mean

Uji Augmented Dickey-Fuller (ADF) merupakan salah satu uji yang paling sering digunakan dalam pengujian stasioneritas data yakni dengan melihat apakah terdapat akar unit (kondisi tidak stasioner) pada model atau tidak. Uji ADF memiliki hipotesis sebagai berikut:

Hipotesis:

$\mathrm{H}_{0}: \delta=0$, data tidak stasioner

$\mathrm{H}_{1}: \delta<0$, data stasioner

Taraf signifikansi: $\alpha$

Statistik uji:

$$
T=\frac{\widehat{\delta}}{S E(\widehat{\delta})}
$$

Kriteria uji:

$\mathrm{H}_{0}$ ditolak jika nilai $T$ lebih besar dari titik kritis $T^{*}$ pada tabel Dickey-Fuller atau jika nilai $p$-value $<\alpha$ 
b. Uji Stasioneritas dalam Varian

Transformas Box-Cox dapat dilakukan untuk menstasionerkan data runtun waktu yang tidak stasioner dalam varian. Secara matematis transformasi Box-Cox menurut Soleymani (2018) dapat dirumuskan:

\subsection{Analisis Runtun Waktu}

$$
Y^{(\lambda)}= \begin{cases}\frac{\left(Y^{\lambda}-1\right)}{\lambda}, & \lambda \neq \mathbf{0} \\ \log Y, & \lambda=\mathbf{0}\end{cases}
$$

\section{a. Automatic ARIMA}

Menurut (Rosadi, 2008) untuk menentukan model ARIMA terbaik dapat diperoleh melalui fungsi auto.arima(). Penggunaan fungsi auto.arima() ini menggunakan variasi algoritma Hyndman-Khandakar yang menggabungkan uji unit root, nilai AIC terkecil, dan MLE untuk mendapatkan model ARIMA terbaik (Hyndman dan Khandakar, 2008). Algoritma Hyndman-Khandakar untuk pemodelan automatic ARIMA adalah sebagai berikut:

1. Menentukan jumlah differensi $0 \leq d \leq 2$ menggunakan uji KPPS (KwiatkoskiPhillips-Schmidt-Shin test) atau uji akar unit berulang.

2. Menentukan nilai $p$ dan $q$ dengan meminimalkan nilai AIC setelah dilakukan differensi $d$. algoritma ini menggunakan pencarian bertahap untuk pemodelan, sehingga tidak perlu lagi mempertimbangkan setiap kemungkinan kombinasi antara $p$ dan $q$.

Nilai AIC (Akaike's Information Criterion) dapat digunakan untuk menentukan pemilihan model terbaik. Model yang terbaik adalah model yang memiliki nilai AIC yang minimal. Rumus untuk memperoleh nilai AIC ditulis sebagai berikut (Rosadi, 2012):

$$
\mathrm{AIC}=n \log \left(\frac{S S R}{n}\right)+2 k
$$

b. Uji Lagrange Multiplier (LM)

Uji Lagrange Multiplier (LM) diperkenalkan oleh Engle (1982) digunakan untuk mengecek ada tidaknya efek ARCH. Berikut merupakan langkah pengujian hipotesis untuk mengetahui ada atau tidaknya efek ARCH/GARCH

Hipotesis:

$\mathrm{H}_{0}: \alpha_{1}=\alpha_{2}=\cdots=\alpha_{m}=0$ (tidak ada efek ARCH/GARCH dalam residual sampai lag ke-m)

$\mathrm{H}_{1}$ : paling sedikit ada $\operatorname{satu} \alpha_{i} \neq 0 \quad i=1,2, \ldots, m$ (ada efek ARCH/GARCH dalam residual sampai lag ke- $m$ )

Taraf Signifikansi: $a$

Statistik uji:

$$
\mathrm{LM}=\mathrm{nR}^{2}
$$

Kriteria uji:

$\mathrm{H}_{0}$ ditolak jika nilai probabilitas $\mathrm{LM}>\chi_{m}{ }^{2}$ atau $p$-value $<a$

c. Model ARCH dan GARCH

Model pertama yang digunakan untuk memodelkan volatilitas residual data adalah model Autoegressive Conditional Heteroscedasticity (ARCH) yang diperkenalkan oleh Engle (1982). Bentuk umum dari model $\operatorname{ARCH}(p)$ menurut Tsay (2002):

$$
\sigma_{t}^{2}=\alpha_{0}+\alpha_{1} a^{2}{ }_{t-1}+\cdots+a^{2}{ }_{t-p}
$$

Bollerslev (1986) mengembangkan model ARCH ke dalam model yang lebih umum yang dikenal sebagai Generalized Autoregressive Conditional Heteroscedasticity $(\mathrm{GARCH})$. Secara matematis model $\operatorname{GARCH}(p, q)$ dapat dibuat dalam bentuk berikut (Tsay, 2002): 


$$
\sigma_{t}^{2}=\alpha_{0}+\sum_{i=1}^{p} \alpha_{0} a_{t-1}^{2}+\sum_{j=1}^{q} \beta_{j} \sigma_{t-1}^{2}
$$

\section{d. Uji Sign Bias}

Uji sign bias digunakan untuk mengetahui apakah terdapat pengaruh asimetrik atau tidak pada data. Untuk memeriksa apakah terdapat pengaruh asimetris, data terlebih dahulu dimodelkan ke dalam model GARCH dan diambil residual datanya. Kemudian lakukan uji efek asimetris berdasarkan persamaan regresi berikut (Brook, 2008):

$$
a_{t}^{2}=\varphi_{0}+\varphi_{1} S_{t-1}^{-}+\varphi_{2} S_{t-1}^{-} a_{t-1}+\varphi_{3} S_{t-1}^{+} a_{t-1}+e_{t}
$$

Pengujian parameter pada persamaan (27) dilakukan dengan langkah berikut:

Hipotesis:

$\mathrm{H}_{0}: \varphi_{1}=\varphi_{2}=\varphi_{3}=0$ (residual tidak bersifat asimetris)

$\mathrm{H}_{1}$ : paling sedikit ada satu $\varphi_{j} \neq 0$ untuk $\mathrm{j}=1,2,3$ (residual bersifat asimetris)

Taraf signifikansi: $\alpha$

Statistik uji:

$$
\mathrm{LM}=\mathrm{nR}^{2}
$$

Kriteria uji:

$\mathrm{H}_{0}$ ditolak jika $L M>\chi_{(\alpha, 3)}^{2}$ atau $p$-value $<\alpha$

e. Model EGARCH

Exponential GARCH diajukan Nelson pada tahun 1991 untuk menutupi kelemahan model ARCH/GARCH dalam menangkap fenomena ketidakseimbangan (ketidaksimetrisan) antara gejolak positif ( good news) dan gejolak negatif ( $\mathrm{bad}$ news) dalam volatilitas. Secara umum, proses EGARCH pada orde $p$ dan atau $\operatorname{EGARCH}(p, q)$ didefinisikan sebagai berikut:

$$
\ln \sigma_{t}^{2}=\alpha_{0}+\sum_{i=1}^{p} \alpha_{1}\left|\frac{\alpha_{t-1}}{\alpha_{t-j}}\right|+\sum_{i=1}^{q} \beta_{j} \ln \left(\sigma_{t-j}^{2}\right)+\sum_{k=1}^{r} \underset{j=1}{p} \gamma_{j} \frac{\alpha_{t-k}}{\sigma_{t-k}}
$$

Dengan $\alpha_{0}, \alpha_{i}, \beta_{j}$ merupakan konstanta parameter model $\operatorname{EGARCH}(p, q)$.

\subsection{Copula}

Menurut Sklar (1959), copula digambarkan sebagai suatu fungsi yang menjaring berbagai bentuk distribusi marginal kesuatu bentuk distribusi gabungan. Copula Archimedean memiliki 3 kelompok penting yang disebut dengan keluarga Gumbel, Frank dan Clayton. Keluarga copula Archimedean paling banyak digunakan dalam kasus bivariat.

Menurut Nelson (2006) Copula Archimedean yang memiliki dimensi $d$, dapat didefinisikan dengan:

$$
C\left(u_{1}, \ldots, u_{d}\right)=\phi^{-1}\left(\phi\left(u_{1}\right)+\cdots+\phi\left(u_{d}\right)\right)
$$

Fungsi $\phi$ disebut sebagai generator copula, dengan asumsi bahwa generator $\phi$ hanya memiliki satu parameter, yaitu $\theta$.

Fleksibilitas copula Arcimedian diberikan oleh fungsi $\phi$, misal dari copula Clayton, copula Frank, dan copula Gumbel (Scholzel, 2008) adalah sebagai berikut:

$$
\begin{aligned}
& \phi_{C}(u)=\frac{1}{\theta_{C}}\left(u^{-\theta_{C}}-1\right), \theta_{C}>0 \text { (Clayton) } \\
& \phi_{F}(u)=\log \left(\frac{e^{\theta} F^{u}-1}{e^{\theta} F-1}\right), \theta_{F} \neq 0 \text { (Frank) } \\
& \phi_{G}(u)=-\log u^{\theta_{G}}, \theta_{G} \geq 1 \text { (Gumbel) }
\end{aligned}
$$

Untuk copula Archimedian pada kasus bivariat dapat ditulis sebagai berikut:

$$
C\left(u_{1}, u_{2}\right)=\phi^{-1}\left(\phi\left(u_{1}\right)+\phi\left(u_{2}\right)\right)
$$

a. Copula Frank

Copula Frank adalah bagian dari copula Archimedean yang paling sering digunakan dan merupakan copula Archimedean yang paling dikenal dalam menyelasaikan kasus empirisis (Cherubini et al, 2004). Diketahui fungsi generator copula Frank dan invers fungsi generator copula Frank 


$$
\varphi(u)=-\ln \frac{e^{-\theta i}-1}{e^{-\theta}-1}
$$

dengan fungsi generator diatas, akan menghasilkan masing masing fungsi distribusi kumulatif copula Frank sebagai berikut:

\section{b. Uji Saling Ketergantungan}

$$
C\left(u_{1}, u_{2}\right)=-\frac{1}{\theta} \ln \left(1+\frac{\left(e^{-\theta u_{1}}-1\right)\left(e^{-\theta u_{2}}-1\right)}{e^{-\theta}-1}\right)
$$

Uji saling ketergantungan dilakukan untuk mengetahui adanya dependensi di antara masing-masing variabel dalam sebuah pemodelan distribusi bersama. Korelasi Kendall $(\tau)$ adalah korelasi berbasis rank dan tidak memerlukan asumsi kenormalan data. Menurut Genest dan Favre (2007) pengukuran koefisien korelasi Kendall $(\tau)$ secara empiris ditulis sebagai berikut:

Hipotesis:

$$
\tau=\frac{P_{n}-Q_{n}}{\left(\begin{array}{c}
n \\
2
\end{array}\right)}
$$

$$
\begin{aligned}
& \mathrm{H}_{0}: \tau=0 \text { (tidak ada korelasi) } \\
& \mathrm{H}_{1}: \tau \neq 0 \text { (ada korelasi) }
\end{aligned}
$$

Taraf signifikansi: $\alpha$

Statistik uji:

\section{Kriteria uji:}

$$
Z=\sqrt{\frac{9 n(n-1)}{2(2 n+5)}}|\tau|
$$

$\mathrm{H}_{0}$ ditolak jika $\mid \mathrm{Z}$-hitung $\mid>$ quantil $\frac{\alpha}{2}$ dari distribusi Normal baku atau $p$-value $<\alpha$

c. Estimasi Copula Frank

Menurut Cherubini et al. (2004) satu-satunya teori yang dapat digunakan untuk mendapatkan estimasi parameter copula yakni menggunakan metode Maximum Likelihood Estimation (MLE). Bentuk fungsi likelihood L dalam kasus bivariat dapat ditulis sebagai berikut:

$$
L=\prod_{i=1}^{2} C\left(u_{1}, u_{2}\right)\left\{F_{1}\left(x_{1}\right), F_{2}\left(x_{2}\right)\right\} f_{1}\left(x_{1}\right) f_{2}\left(x_{2}\right)
$$

Dapat diuraikan menjadi:

$$
\ln f\left(x_{1} ; x_{2} ; \theta ; \rho\right)=\ln c\left(F_{1}\left(x_{1} ; \theta\right), F_{2}\left(x_{2} ; \theta\right) ; \rho\right)+\ln f_{1}\left(x_{1} ; \theta\right)+f_{2}\left(x_{2} ; \theta\right)
$$

Dimana parameter $\rho$ menunjukkan dependensi keseluruhan antara dua variabel random dan $\theta$ adalah kumpulan dari semua parameter marginal dan copula

\subsection{Value at Risk}

VaR merupakan alat ukur yang dapat menghitung besarnya kerugian terbentuk yang dapat terjadi dengan mengetahui posisi aset, tingkat kepercayaan akan terjadinya risiko, dan jangka waktu penempatan aset (time horizon) (Jorion, 2006). Menurut Maruddani dan Purbowati (2009), nilai VaR pada tingkat kepercayaan $(1-\alpha)$ dalam periode waktu t hari pada return tunggal maupun portofolio dapat dihitung dengan:

$$
\operatorname{VaR}_{(1-\alpha)}(t)=W_{0} R^{*} \sqrt{t}
$$

Penelitian ini menggunakan metode simulasi Monte-Carlo. Simulasi Monte-Carlo digolongkan metode sampling karena input dibangkitkan secara random dari suatu distribusi probabilitas untuk proses sampling dari suatu populasi nyata.

\subsection{Backtesting}

Menurut Christianti (2010) backtesting berguna bagi pengguna VaR dan manajer risiko untuk mengkaji apakah peramalan VaR telah terkalibrasi dengan baik. Metode backtesting yang digunakan pada penelitian ini adalah Kupiec Test. Untuk menentukan 
validitas pengujian model VaR dapat menggunakan pendekatan loglikelihood ratio (Jorion, 2007) dengan persamaan sebagai berikut:

$$
L R=-2 \ln \left[\left(1-p^{*}\right)^{n-x}\left(p^{*}\right)^{x}\right]+2 \ln \left[\left(1-\left[\frac{x}{n}\right]\right)^{n-x}\left(\left[\frac{x}{n}\right]\right)^{x}\right]
$$

Pengujian dilakukan dengan membandingkan nilai perhitungan likelihood ratio (LR) dengan critical value (CR) distribusi Chi-square $\left(\chi^{2}\right)$. Apabila nilai dari LR lebih kecil dari $\mathrm{CR}$, maka hipotesis nol diterima yang menunjukkan bahwa model VaR valid.

\section{METODE PENELITIAN}

Data yang digunakan dalam penelitian ini adalah data sekunder harga penutupan (closing price) saham harian PT. Kalbe Farma Tbk (KLBF) dan PT. Bank Central Asia Tbk (BBCA) pada periode 30 Desember 2011 - 6 Desember2019 pada hari aktif. Data harga penutupan saham tersebut dapat diakses pada situs www.finance.yahoo.com.

Adapun langkah-langkah yang dilakukan dalam melakukan analisis data estimasi VaR dari portofolio saham menggunakan metode copula-EGARCH adalah :

1. Menghitung return berdasarkan data closing price.

2. Menghitung dan menganalisis statistika deskriptif return saham.

3. Melakukan pengujian kestasioneran data return saham menggunakan uji Augmented Dickey-Fuller dan Transformasi Box-Cox.

4. Melakukan pemilihan model terbaik dengan fungsi auto.arima () .

5. Melakukan verifikasi model yang meliputi uji diagnostik yang terdiri dari uji independensi residual dan uji normalitas model.

6. Melakukan uji Lagrange Multiplier untuk mengetahui apakah ada efek ARCH/GARCH dalam model.

7. Melakukan identifikasi model ARCH/GARCH.

8. Melakukan uji efek asimetris dengan menggunakan uji sign and size bias test pada model GARCH.

9. Melakukan identifikasi model EGARCH.

10. Melakukan uji Lagrange Multiplier untuk mengetahui masih ada/tidaknya efek ARCH/GARCH dalam model.

11. Menghitung korelasi antara saham BBCA dan KLBF dengan menggunakan korelasi Tau-Kendall.

12. Membentuk dan mengombinasikan residual model ARIMA-EGARCH ke Frankcopula.

13. Menghitung nilai Value at Risk (VaR) dari persentil-persentil dengan menggunakan metode simulasi Monte-Carlo.

14. Melakukan uji backtesting dengan menggunakan metode Kupiec Test untuk mengetahui keakuratan nilai Value at Risk (VaR) yang telah dihasilkan.

15. Membuat kesimpulan dari hasil analisis berdasarkan Value at Risk (VaR) dari kombinasi saham dan didapatkan nilai Value at Risk (VaR) dengan selang kepercayaan (1- $\alpha$ ) dengan taraf signifikansi $\alpha$.

\section{HASIL DAN PEMBAHASAN}

\subsection{Karakeristik Data Saham}

Data yang digunakan pada penelitian ini yaitu data sekunder harga penutupan (closing price) saham harian dari PT. Bank Central Asia, Tbk (BBCA) dan PT. Kalbe Farma, Tbk (KLBF) periode 30 Desember 2011 - 6 Desember 2019 pada hari aktif (Senin sampai Jumat). 

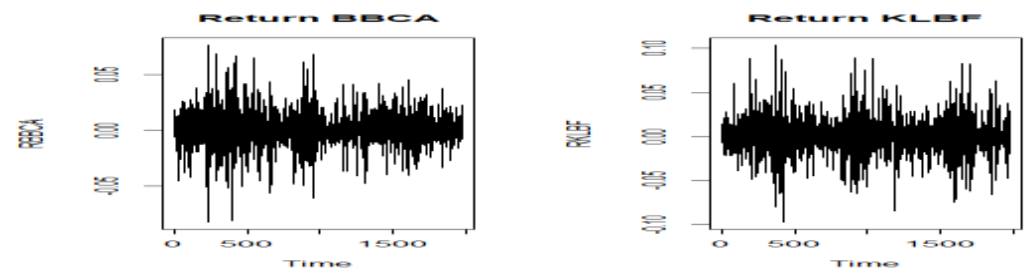

Gambar 1. Plot Return Closing Price Saham BBCA dan KLBF

Terlihat bahwa plot data return saham BBCA dan KLBF menunjukkan pola fluktuasi naik turun sepanjang periode. Fluktuasi yang tinggi menunjukkan volatilitas yang tinggi pula. Selain itu terjadi volatility clustering yakni terjadi variabilitas data yang relatif tinggi juga, terlihat pada suatu waktu dan terjadi kecenderungan yang sama dalam kurun waktu selanjutnya. Sehingga secara visual, data return menunjukkan adanya kasus heteroskedastisitas.

Karakteristik data return saham BBCA dan KLBF pada periode 30 Desember 2011 sampai dengan 6 Desember 2019 dapat disajikan dalam Tabel 1.

Tabel 1. Statistik Deskriptif Data Return Saham BBCA dan KLBF

\begin{tabular}{lrr}
\hline \multicolumn{1}{c}{ Variabel } & \multicolumn{1}{c}{ BBCA } & KLBF \\
\hline Jumlah Observasi & 1984 & 1984 \\
Mean & 0,00069 & 0,00042 \\
Skewness & $-0,06121$ & 0,19226 \\
Kurtosis & 6,77475 & 6,11547 \\
\hline
\end{tabular}

Dari Tabel 1 dapat diketahui bahwa kedua saham tersebut memiliki nila rata-rata bernilai positif yakni untuk saham BBCA sebesar 0,00069 dan untuk saham KLBF sebesar 0,00042 . Hal ini menunjukkan bahwa kedua saham tersebut akan memberikan keuntungan bagi para investor. Selain itu, nilai kurtosis return kedua saham memilik nilai kurtosis lebih besar dari 3 sehingga menghasilkan kurva leptokurtosis (meruncing). Data return tersebut mengindikasikan bahwa adanya ekor gemuk dan tidak berdistribusi secara normal.

\subsection{Automatic ARIMA}

Penentuan model ARIMA terbaik dapat diperoleh secara otomatis dengan menggunakan fungsi auto arima () yang terdapat pada package forecast dalam software R. Model $\operatorname{ARIMA}(p, d, q)$ terbaik yang terbentuk dengan menggunakan fungsi auto. arima ( ) untuk data return saham BBCA yaitu ARIMA $(1,0,1)$ dengan konstanta sedangkan untuk data return saham KLBF yaitu ARIMA $(1,0,1)$ tanpa konstanta.

\subsubsection{Estimasi Parameter Model}

Model ARIMA $(1,0,1)$ dengan konstanta untuk data return saham BBCA dan $\operatorname{ARIMA}(1,0,1)$ tanpa konstanta untuk data return saham KLBF dapat digunakan analisis lebih lanjut karena pada taraf signifikansi $\alpha=5 \%$ semua parameternya signifikan terhadap model dengan memiliki nilai $p$-value lebih kecil dari $\alpha=0,05$ seperti yang tersaji pada Tabel 2.

Tabel 2. Hasil Estimasi Parameter Model ARIMA

\begin{tabular}{cccccc}
\hline Saham & Model & Parameter & Koefisien & P-value & Keputusan \\
\hline BBCA & ARIMA $(1,0,1)$ & $\mathrm{C}$ & 0,000696 & 0,002227 & $\mathrm{H}_{0}$ ditolak \\
& & $\phi_{1}$ & 0,717363 & $<2,2 \mathrm{e}-16$ & $\mathrm{H}_{0}$ ditolak \\
& & $\theta_{1}$ & $-0,801223$ & $<2,2 \mathrm{e}-16$ & $\mathrm{H}_{0}$ ditolak \\
KLBF & ARIMA $(1,0,1)$ & $\phi_{1}$ & 0,791726 & $<2,2 \mathrm{e}-16$ & $\mathrm{H}_{0}$ ditolak \\
& & $\theta_{1}$ & $-0,854917$ & $<2,2 \mathrm{e}-16$ & $\mathrm{H}_{0}$ ditolak \\
\hline
\end{tabular}

\subsection{Uji Lagrange Multiplier (LM)}

Uji Lagrange Multiplier (LM) digunakan untuk mengetahui ada atau tidaknya efek ARCH/GARCH atau efek heteroskedastisitas pada residual model ARIMA yang terbentuk 
sebelumnya. Hasil yang diperoleh untuk model ARIMA dari data return saham BBCA maupun data return saham $\mathrm{KLBF} \mathrm{H}_{0}$ ditolak karena mempunyai nilai $p$-value $<a=5 \%$ sehingga dapat disimpulkan bahwa terdapat efek heteroskedastisitas pada residual maka dilanjutkan dengan pemodelan ARCH/GARCH.

\subsection{Model ARCH dan GARCH}

Alternatif model yang digunakan adalah model $\operatorname{GARCH}(p, q)$ dengan orde $p$ dan $q$ sebesar $\leq 2$ untuk menghindari pemodelan volatilitas dengan orde yang tinggi pada model $\operatorname{ARCH}(p)$ (Rosadi, 2012). Model awal yang terbentuk untuk data return saham BBCA maupun $\operatorname{KLBF}$ adalah $\operatorname{ARIMA}(1,0,1) \operatorname{GARCH}(1,1)$ dan $\operatorname{ARIMA}(1,0,1) \operatorname{GARCH}(1,2)$. Selanjutnya dilakukan dilakukan estimasi parameter dan uji signifikansi parameter diperoleh bahwa model terbaik untuk data return saham BBCA maupun untuk data return saham KLBF yaitu $\operatorname{ARIMA}(1,0,1) \quad \operatorname{GARCH}(1,1)$ dan $\operatorname{ARIMA}(1,0,1) \operatorname{GARCH}(1,2)$ dapat digunakan untuk analisis lebih lanjut karena pada taraf signifikansi $\alpha=5 \% \mathrm{H}_{0}$ ditolak, sehingga dapat disimpulkan bahwa semua parameternya telah signifikan terhadap model dengan memiliki nilai $p$-value yang lebih kecil dari $\alpha=0,05$.

\subsection{Uji Efek Asimetris}

Pengujian ini dilakukan untuk mengetahui apakah terdapat perbedaan pengaruh residual positif ( good news) dan residual negatif (bad news) terhadap volatilitas data. Diperoleh bahwa untuk data return saham BBCA cukup digunakan model ARIMA $(1,0,1)$ GARCH $(1,1)$ karena memiliki nilai $p$-value untuk uji negative size bias sebesar 0,02623 dan uji join effect sebesar 0,04981 sehingga $\mathrm{H}_{0}$ ditolak karena nilai $p$-value lebih kecil dari $\alpha=$ 0,05 . Untuk data return saham $\operatorname{KLBF}$ pada model $\operatorname{ARIMA}(1,0,1) \operatorname{GARCH}(1,1)$ memiliki nilai $p$-value untuk uji negative size bias sebesar 0,00472 dan uji join effect sebesar 0,0437 sehingga sehingga $\mathrm{H}_{0}$ ditolak karena nilai $p$-value lebih kecil dari $\alpha=0,05$ sedangkan untuk model ARIMA $(1,0,1) \operatorname{GARCH}(1,2)$ memiliki nilai $p$-value untuk uji negative size bias sebesar 0,0286 sehingga $\mathrm{H}_{0}$ ditolak karena nilai $p$-value lebih kecil dari $\alpha=0,05$. Jadi, pada taraf signifikansi $\alpha=0,05$ dapat disimpulkan bahwa untuk data return saham BBCA pada model ARIMA(1,0,1) GARCH $(1,1)$ data return saham KLBF pada model ARIMA $(1,0,1)$ $\operatorname{GARCH}(1,1)$ dan $\operatorname{ARIMA}(1,0,1) \operatorname{GARCH}(1,2)$ mengindikasikan terdapat efek asimetris sehingga untuk mengatasinya dapat dilakukan analisis lebih lanjut menggunakan GARCH asimetris yaitu dengan pemodelan EGARCH.

\subsection{Model EGARCH}

Model EGARCH yang terbentuk untuk data return saham BBCA adalah ARIMA(1,0,1) EGARCH $(1,1)$ sedangkan untuk data return saham $\operatorname{KLBF}$ adalah $\operatorname{ARIMA}(1,0,1)$ EGARCH(1.1) dan ARIMA(1,0,1) EGARCH(1,2). Setelah dilakukan estimasi parameter dan uji signifikansi parameter diperoleh bahwa model untuk data return saham BBCA adalah ARIMA $(1,0,1)$ EGARCH $(1,1)$ sedangkan untuk data return saham KLBF adalah $\operatorname{ARIMA}(1,0,1)$ EGARCH$(1,2)$ dapat digunakan analisis lebih lanjut karena pada taraf signifikansi $a=5 \%$ semua parameternya signifikan terhadap model dengan memiliki nilai $p$-value lebih kecil dari $\alpha=0,05$.

\subsection{Uji Lagrange Multiplier Model EGARCH}

Uji Lagrange Multiplier digunakan untuk mengetahui apakah masih terdapat efek ARCH/GARCH atau heteroskedastisitas pada residual model EGARCH yang terbentuk sebelumnya. Diperoleh hasil bahwa $\mathrm{H}_{0}$ diterima untuk semua model karena nilai $p$-value lebih besar dari $a=0,05$. Jadi, pada taraf signifkasi $a=5 \%$ dapat disimpulkan bahwa sudah tidak terdapat efek heteroskedastisitas pada residual maka model yang terbentuk dari data return saham BBCA yaitu model ARIMA $(1,0,1) \operatorname{EGARCH}(1,1)$ sedangkan dari data return saham KLBF yaitu model $\operatorname{ARIMA}(1,0,1) \quad \operatorname{EGARCH}(1,1)$ dan $\operatorname{ARIMA}(1,0,1)$ $\operatorname{EGARCH}(1,2)$. 


\subsection{Pemilihan Model Terbaik}

Model terbaik merupakan model yang memiliki nilai AIC dan SBC yang minimal (Rosadi, 2011). Diperoleh hasil bahawa untuk data return saham BBCA telah didapatkan model ARIMA-EGARCH yaitu ARIMA $(1,0,1)$ EGARCH( 1,1$)$ sedangkan untuk data return saham KLBF perlu adanya pemilihan model terbaik berdasarkan nilai AIC dan SBC terkecil terdapat pada Tabel 3.

Tabel 3. Pemilihan Model Terbaik Data Return Saham KLBF

\begin{tabular}{cr}
\hline Model & Nilai AIC \\
\hline ARIMA(1,0,1) EGARCH(1,1) & $-5,1928$ \\
ARIMA(1,0,1) EGARCH(1,2) & $-5,1959$ \\
\hline
\end{tabular}

Dari Tabel 3 dapat diketahui bahwa model ARIMA(1,0,1) $\operatorname{EGARCH}(1,2)$ merupakan model terbaik karena memiliki nilai AIC dan SBC yang paling kecil yaitu sebesar -5,1959 dan $-5,1761$ sehingga diperoleh persamaan model masing-masing saham sebagai berikut:

Untuk data return saham BBCA

$$
\begin{aligned}
& \hat{Z}_{t}=0.791726 Z_{t-1}-0,681505 a_{t-1}+a_{t} \\
& \ln \hat{\sigma}_{t}^{2}=-0,529132-0,056485\left|\frac{\alpha_{t-1}}{\sigma_{t-1}}\right|+0,936119 \ln \left(\sigma_{t-1}^{2}\right)+0,198011 \frac{\alpha_{t-1}}{\sigma_{t-1}} \\
& \text { Untuk data return saham KLBF } \\
& \hat{Z}_{t}=0,701227 Z_{t-1}-0,779134 a_{t-1}+a_{t} \\
& \ln \hat{\sigma}_{t}^{2}=-0,472894-0,071725\left|\frac{\alpha_{t-1}}{\sigma_{t-1}}\right|+0,581170 \ln \left(\sigma_{t-1}^{2}\right)+ \\
& \qquad 0,357247\left(\sigma_{t-2}^{2}\right)+0,253540 \frac{\alpha_{t-1}}{\sigma_{t-1}}
\end{aligned}
$$

\subsection{Copula}

Pada pembentukan Copula, data yang digunakan adalah residual return saham BBCA dan KLBF pada model ARIMA-EGARCH.

a. Transformasi Uniform $[0,1]$

Transformasi merupakan langkah awal yang dilakukan untuk melakukan analisis terhadap copula.

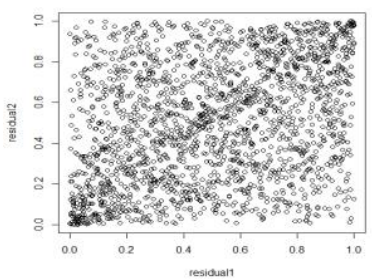

Gambar 2. Scatterplot Residual Model ARIMA-EGARCH Saham BBCA dan KLBF pada Transformasi Uniform [0,1]

Pada Gambar 2 terlihat bentuk scatterplot setelah ditransformasi menunjukkan adanya sebaran titik yang tidak hanya terkonsentrasi pada bagian ujung bawha saja melainkan juga terkonsentrasi pada bagian ujung atas. Hal ini mengindikasikan adanya tail dependence bagian atas dan bawah yakni Copula-Frank.

b. Uji Dependensi Residual

Korelasi Kendall $(\tau)$ digunakan untuk mengukur dependensi antara residual return saham BBCA dan KLBF pada model ARIMA-EGARCH. Diperoleh hasil nilai $p$-value sebesar $<2,2 \mathrm{e}-16$ dan nilai $\tau$ sebesar 0,223491 sehingga pada taraf signifikansi $\alpha=0,05 \mathrm{H}_{0}$ ditolak karena nilai $p$-value lebih kecil dari $\alpha=0,05$ maka dapat disimpulkan bahwa data return saham BBCA-KLBF memiliki korelasi yaitu sebesar 0,2234914.

c. Estimasi Parameter Copula 
Estimasi parameter copula dihitung dengan menggunakan maximum likelihood estimation (MLE) dengan menggunakan nilai Kendall $(\tau)$ dari residual model ARIMAEGARCH saham BBCA dan KLBF yakni sebesar $\tau$ sebesar 0,223491. Didapatkan estimasi parameter Copula-Frank $\hat{\theta}=2,097$. Sehingga model Copula-Frank untuk residual ARIMA-EGARCH saham BBCA dan KLBF adalah

$$
C_{2,097}^{F r}\left(u_{1}, u_{2}\right)=-\frac{1}{2,097} \log \left(1+\frac{\left(e^{-2,097 u_{1}-1}\right)\left(e^{-2,097 u_{2}}-1\right)}{e^{-2,097}-1}\right)
$$

Nilai $\hat{\theta}>0$ menunjukkan copula memiliki dependensi positif yang artinya jika residual model ARIMA-EGARCH saham BBCA naik, maka residual model ARIMA-EGARCH saham KLBF akan naik.

\subsection{Perhitungan Value at Risk}

Perhitungan VaR dalam penelitian ini menggunakan simulasi Monte-Carlo dengan membangkitkan data 1984 data bangkitan dan dengan 100 kali perulangan. Berdasarkan hasil perhitungan nilai VaR dengan ukuran dependensi Copula-Frank diperoleh nilai VaR pada tingkat kepercayaan 95\% yaitu sebesar -0,02233, maka kemungkinan kerugian pada satu hari ke depan yang ditanggung oleh investor sebesar 2,233\% dari investasi hari ini.

\subsection{Uji Validitas VaR}

Pengujian ini dilakukan untuk mengetahui model VaR yang digunakan valid atau tidak. Pada penelitian ini uji validitas menggunakan metode backtesting dan Kupiec Test. Berdasarkan perhitungan rasio pelanggaran pada tingkat kepercayaan 95\% diperoleh nilai $\mathrm{LR}=0,4506823$ lebih kecil dari $\mathrm{CV}=3,84$ maka $\mathrm{H}_{0}$ diterima sehingga dapat disimpulkan bahwa perhitungan VaR menggunakan ARIMA-EGARCH Copula-Frank dinyatakan valid dan baik digunakan.

\section{KESIMPULAN}

Berdasarkan hasil dan pembahasan mengenai perhitungan Value at Risk dengan menggunakan kombinasi antara model asimetris EGARCH dengan Copula-Frank pada saham PT. Bank Central Asia, Tbk dan saham PT. Kalbe Farma, Tbk periode 30 Desember 2011 - 6 Desember 2019, maka diperoleh kesimpulan sebagai berikut:

1. Model ARIMA-EGARCH terbaik pada model return saham BBCA dan KLBF sebgai berikut:

Untuk data return saham BBCA

$$
\begin{aligned}
& \hat{Z}_{t}=0.791726 Z_{t-1}-0,681505 a_{t-1}+a_{t} \\
& \ln \hat{\sigma}_{t}^{2}=-0,529132-0,056485\left|\frac{\alpha_{t-1}}{\sigma_{t-1}}\right|+0,936119 \ln \left(\sigma_{t-1}^{2}\right)+0,198011 \frac{\alpha_{t-1}}{\sigma_{t-1}} \\
& \text { Untuk data return saham KLBF } \\
& \hat{Z}_{t}=0,701227 Z_{t-1}-0,779134 a_{t-1}+a_{t} \\
& \ln \hat{\sigma}_{t}^{2}=-0,472894-0,071725\left|\frac{\alpha_{t-1}}{\sigma_{t-1}}\right|+0,581170 \ln \left(\sigma_{t-1}^{2}\right)+ \\
& \quad 0,357247\left(\sigma_{t-2}^{2}\right)+0,253540 \frac{\alpha_{t-1}}{\sigma_{t-1}}
\end{aligned}
$$

2. Estimasi parameter copula-Frank diperoleh berdasarkan metode MLE. Estimasi parameter copula-Frank yang didapatkan yaitu $\hat{\theta}=2,097$ dan nilai $\tau=0,2234914$. Sehingga didapatkan model copula-Frank sebagai berikut:

$$
C_{2,097}^{F r}\left(u_{1}, u_{2}\right)=-\frac{1}{2,097} \log \left(1+\frac{\left(e^{-2,097 u_{1}-1}\right)\left(e^{-2,097 u_{2}}-1\right)}{e^{-2,097}-1}\right)
$$

3. Perhitungan Value at Risk yang didapatkan menggunakan metode copula-Frank dengan simulasi Monte-Carlo pada periode waktu 1 hari kedepan dengan tingkat kepercayaan $95 \%$ yaitu sebesar 0,02232676 . 
4. Berdasarkan hasil Kupiec backtesting pada tingkat kepercayaan 95\% perhitungan Value at Risk dengan menggunakan metode ARIMA-EGARCH copula-Frank dinyatakan valid dan baik digunakan untuk menghitung Value at Risk indeks saham yang kebergantungan antar saham dalam portofolionya tidak linier.

\section{DAFTAR PUSTAKA}

Arna, N. U. S., Raupong dan Anisa. 2017. Pemodelan Dependensi Distribusi Variabel Non Gaussian Dengan Copula Frank Menggunakan Korelasi Rho Spearman. Fakultas Matematika dan Ilmu Pengetahuan Alam. Universitas Hasanuddin. Makassar.

Brook, C. 2008. Introductory Eonometrics for Finance Second Edition. New York: Cambridge University Press.

Cherubini, U., Luciano, E., dan Vecchiato, W. 2004. Copula Methods in Finance. Wiley Finance Series. UK: John Wiley and Sons, Chichester.

Christianti, dan Ari. 2010. Risiko Pasar: Perbandingan Model EWMA dan GARCH Pada Nilai Tukar Rupiah Terhadap US Dollar. JRMB. Vol. 5, No. 2.

Danielsson, J. 2011. Financial Risk Forecasting The Theory and Practice of Forecasting Market Risk with Implementation in R and Matlab. United Kingdom: John Wiley $\&$ Sons.

Darmadji, T. dan Fakhruddin, H. 2001. Pasar Modal di Indonesia Pendekatan Tanya Jawab. Jakarta: Salemba Empat.

Embrechts, P., Lindskog, F. dan McNeil, A. 2001. Modelling Dependence with Copulas and Aplication to Risk Management. Switzerland: Departement of Mathematics, ETHZ CH-8092 Zürich.

Genest, C. dan Frave, A. C. 2007. Everything You Always Wanted to know about Copula Modeling but Were Afraid to Ask. Inggris: Hydrol.

Hyndman, R. J. dan Khandakar, Y. 2008. Automatic Time Series Forecasting: The Forecast Package for R. Journal of Statistical Software, Vol. 27, No. 3: 1-26.

Kupiec, P. H. 1995. Techniques for Verifying The Accuracy of Risk Measurement Models.The Journal of Derivatives. A Publication of Institusional Investor. New York.

Maruddani, D. A. I. dan Purbowati, A. 2009. Pengukuran Value at Risk pada Kurs Tunggal dan Portofolio dengan Simulasi Monte Carlo. Media Statistika Vol. 2 Hal. 259264.

Nelson, D. B. 1991. Conditional Heteroscedasticity in Asset Return: A New Approach. Journal of Econometrica. Vol. 59, No.2, 357-370.

Rosadi, D. 2012. Ekonometrika dan Analisis Waktu Terapan dengan Eviews. Yogyakarta: Andi Offset.

Sklar, A. 1959. Fonctions de Repartition an Dimensions et Leurs Marges. Publications de I'Institut Statistique de I'Université de Paris, Vol 8 Hal 229-231.

Tsay, R. S. 2002. Analysis of Financial Time Series. Canada : John Wiley and Sons, Inc. 